\title{
Perception of Teachers and Students Towards the Implementation of Choice Based Credit System at Undergraduate Level
}

\author{
Sonia Mahakur, Rajashree Baral and Venkateswar Meher ${ }^{*}$ \\ School of Education Gangadhar Meher University, Sambalpur, Odisha-768004, India \\ *Email: venkatesmeher90@gmail.com
}

\section{ARTICLE INFORMATION}

Received: October 16, 2018

Revised: November 27, 2018

Accepted: February 09, 2019

Published online: March 04, 2019

Keywords:

Perception, Choice Based Credit System,

Undergraduate level

\begin{abstract}
The present study examines the perception of teachers and students of undergraduate colleges towards the implementation of Choice Based Credit System (CBCS) by investigating the significance of difference in the perception of teachers in relation to stream and students in relation to sex, streams and types of colleges. For this purpose near about 60 teachers and 120 students were selected through random sampling from 4 undergraduate colleges of Bargarh district affiliated to Sambalpur University, Odisha. The descriptive survey method was used by the researchers. The data were collected through five point perception scale developed by the researchers for teachers and students separately. For the analysis of the obtained data test was used. The result indicated that Arts, Science and Commerce teachers did not differ significantly in their perception towards implementation of CBCS at undergraduate level. The Science students differed significantly from the Commerce and Arts students in their perception towards the implementation of CBCS at undergraduate level. But Arts and Commerce students did not differ significantly in their perception. There was no significant difference in the perception of male and female students. The students of Government College differed significantly from the students of private college and government aided colleges in their perception towards the implementation of CBCS at under graduate level.
\end{abstract}

which focus was given to only quantitative aspects, here much more emphasis is given to the needs and demand of the pupils" (Mishra, 2017). Since the last many decades, higher education in India was found to be unprogressive with traditional procedures of the evaluation system, rigid curriculum and outdated teaching-learning practices which were far below the international standard. As a result, the students coming out of this wireless system had very poor employability. As a result, the CBCS was introduced in order to reform the system and ensure quality and excellence in Higher Educational Institutions (HEIs).

"The CBCS is introduced to bring about changes in higher education system in India with reference to learning opportunities, the ability to match learners' needs in institutions, as well as the desirability of learners' enrollment, the development of quality education and excellence, the great flexibility of completing programs effectively and education programs" (Kelker \& Shankar, 2014). In this system, a uniform curriculum and evaluation system is prescribed which helps to 
bring similarity at higher education level all across the country. It offers a unique course structure having core subjects, generic electives, discipline-specific elective, foundation courses likeability enhancement courses and skill enhancement courses. The students get the freedom to acquire credit as per their own ability. There is freedom of mobility and transfer of credits from one educational institution to another institution throughout the country because of its uniformity. CBCS follows a continuous and comprehensive evaluation system. The semester system and the grading system are followed to evaluate students' performance. In this sense Behera, Meher and Baral (2018) mentioned in their article that the semester system of examination is highly favourable by the undergraduate students from different dimensions. However, this uniform grading system helps the employed to evaluate the students of different universities on the same scale of assessment. However, it was inferred that the CBCS is more effective than the traditional marking system and percentage system, as a result the investigators took keen interest to examine the perception of teacher and students towards the CBCS with regards to its important dimensions. In this regard Shakti, Sethuraman and Adkoli (2016) found out that the majority of dental academicians have accepted the feasibility of implementation of CBCS syllabus, where all students are interested to welcome it.

\section{Related Literatures}

The researchers conducted an intensive review of available kinds of literature related to CBCS, most of the researchers have studied the perception, attitude, teachers, students, administrators government colleges, affiliated colleges, rural and urban colleges, etc. As CBCS has been introduced recently in India, so a very few numbers of studies were found in these fields which are enumerated below.

The findings of Kelker \& Shankar (2014) revealed that $62.5 \%$ of teachers perceived CBCS emphasizing on an evaluation only and only $42 \%$ perceived that its objectives have been fulfilled from their study conducted in Mumbai University. Deuri (2015) conducted a study at Gauhati University and compared the attitude of Science stream and Arts stream students towards the CBCS and found that the mean scores of science students was higher as compared to Arts students, the result also revealed that boys are having the highest level attitude than girls in Gauhati University. There were some conceptual articles where the authors have mentioned about the relevant issues in implementing CBCS. Hasan and Parvez (2015) enumerated about the pros and cons of CBCS in their paper and mentioned that there is no uniformity among universities in selection procedures of teachers, infrastructural facilities and academic environment which may stand as an obstacle in the successful implementation of CBCS. They also expressed that there is a need for open discussion, seminar and among policymakers and educationists, etc. on CBCS. Aitheli and Kumar (2016) mentioned that CBCS is beneficial because of the presence of a better evaluation system such as; grading and semester system in India. Kaur and Sharma (2016) mentioned that $\mathrm{CBCS}$ provides multidisciplinary learning experience but freedom should be given in choosing elective subjects. Naidu and Shreedevi (2016) mentioned in their paper that choice based paper selection and credit transfer is somehow difficult due to certain reasons. So this problem should be solved by making provisions of credit transfer and choice based subject selection. The grading system should be adopted with the marking system and equalization of the standard of all institution is required for students' mobility. Sumitha, Krishnamurti, and Winfred (2016) found no sign of the difference in the perception of students. Kotch (2017) found equality in the outlook of male and female, urban and rural, more experienced and less experienced teachers of degree colleges towards the CBCS in Hamirpur district of HimachalPradesh. Bhat (2017) found in his study that Science students have a high level of an attitude than Arts students towards CBCS at the undergraduate level in government degree colleges of Anantanag Kashmir. Chahal and Manan (2017) found out from their study conducted on the attitude of P.G. students of Science, Arts and Social Science students of central university of Haryana that most of the students are satisfied towards the implementation of CBCS in India. Kapur (2017) depicted that CBCS will raise higher education in India to an international level. But in this system, many universities will lose their autonomy. Uniformity will neglect creativity based on socio-cultural diversity. It will impose a heavy workload on teachers. Ghose and Sarkar (2017) expressed that there is an extra 
burden on teachers towards teaching and examination stress on students in CBCS. Singh (2017) conducted a study on the perception of student and teachers and found out that they are satisfied with the CBCS pattern. Tazien (2017) expressed that the success of CBCS is based on the support of every stakeholder of an academic institution. Biswas (2018) mentioned that CBCS is student friendly but there is need of guidance and counseling for teachers and students for course selection and other issues of CBCS.

\section{Rationale of the Study}

Many studies and published articles on CBCS revealed that it would enhance the workload of teachers and affect the quality of teaching, the students and teachers will have to spend most of their time in internal and semester exams and so on. The literatures also revealed that the variation and lack of infrastructural facilities, human resources will create problem to meet the requirements of CBCS like mobility of students, transfer of credits, the chances of subjectivity in internal exams will affect student's results, etc. and for the slow learners it will be difficult to acquire the required credits in a short time period of the semester system. So after the critical analysis of the literatures it was found that CBCS is recently introduced and in this context the response of the stakeholders of higher educations positive in one hand and negative in other perspectives, therefore the study was undertaken with a purpose to assertion the perception of the stakeholders and attempt was made to make a comparison in their perceptions. The analysis of the above kinds of the literature revealed that most of the studies have been conducted in various Govt. colleges and universities taking into account the perceptions, attitude, and opinion of the stakeholders, especially of higher education. But a very few research studies were found where the perception Commerce teachers towards CBCS is taken into consideration. So, in this present study effort is made to examine the perception of the Arts, Science and Commerce teachers of both government and private colleges and their perception towards the implementation of CBCS is being compared with the help of statistical significance. Numbers of studies were found in different universities in different states of the country, but few studies are found in Odisha, particularly in Sambalpur district on the choice based credit system. Thus an attempt was made to conduct research by taking participants from Govt., private and other affiliated colleges of Sambalpur university in Bargarh district.

\section{Research Questions}

As per the above-discussed pros and cons and needs of the study, several research questions emerged in the mind of the investigator.

1. Do the mean scores of Arts, Science and Commerce stream teachers differ with regards to their perceptions about the implementation of CBCS?

2. Do the perceptions of undergraduate level students differ with regards to the implementation of CBCS in relation to sex, streams, and types of colleges?

The investigators took keen interest in seeking the solutions of the above cited problem in the form of the following topic titled "Perception of Teachers and Students towards the Implementation of Choice Based Credit System (CBCS) at Undergraduate Level”

\section{Objectives of the Study}

1. To compare the perception of teachers belonging from Arts, Science, and Commerce stream towards the implementation of CBCS.

2. To compare the perception of undergraduate boys and girls students towards the implementation of CBCS at the undergraduate level.

3. To compare the perception of students belonging from Arts, Science and Commerce stream towards the implementation of CBCS at the undergraduate level.

4. To compare the perception of students of government, private and government aided college towards the implementation of CBCS.

\section{Hypotheses of the Study}

1. There exists no significant of difference among the perception of teachers belonging from Arts, Science, and Commerce stream towards the implementation of CBCS.

2. There exists no significance of difference between the perception of undergraduate boys and girls students towards the implementation of CBCS at the undergraduate level.

3. The perception of students belonging from Arts, Science and Commerce stream towards the implementation 
of CBCS at the undergraduate level don't differ significantly.

4. The perception of students of government, private and government aided college towards the implementation of CBCS don't differ significantly.

\section{Scope and Delimitations}

- This research study was delimited to the perception of teachers and students towards the implementation of Choice Based Credit System only at the undergraduate level with special focus to the objectives of CBCS, courses, the system of examination and evaluation, etc.

- This paper was confined to 120 Undergraduate students of Arts, Science and Commerce streams only from Bargarh district affiliated to Sambalpur University.

- It was also limited to 4 selected undergraduate colleges having Arts, Science and Commerce streams i.e. 1 Government, 1 private and 2 Government aided colleges affiliated to Sambalpur University.

- The present study was delimited to 60 teachers of selected undergraduate colleges among whom 15 from each colleges representing 5 each from each stream.

\section{Materials \& Methods}

\subsection{Method}

As in this present study effort is taken to compare the perception of students and a teacher towards the implementation of CBCS at undergraduate level, the causal comparative method was used. In this present study the perception of teachers of Arts, Science and Commerce stream is compared in one hand. On the other hand, the perception of students is compared with reference to sex (boys and girls), streams (Arts, Science and Commerce), type of college (private, government, government-aided). So in order to achieve the above cited objectives causal comparative research design was followed.

\subsection{Participants}

The universe of the research study took all the teachers and students of all the undergraduate colleges in Bargarh district affiliated to Sambalpur University. Out of which the researchers selected 4 undergraduate colleges purposively having Arts, Science and Commerce streams, from which 60 teachers were selected randomly in which 5 teachers from each stream were taken as the sample. A total number of 120 students were selected from the selected colleges through random sampling which included 30 students from each stream-Arts, Science, and Commerce. Among the 4 colleges, two were government aided colleges one was Government College and one was private college. So in totally 180 participants were taken into account for conducting the survey.

\subsection{Instrument}

In order to study the perception of the teachers and students the five-point perception scale was developed following standard procedure. The scale was in interval scale, as the samples were taken randomly, and it was proposed to apply parametric statistics for the strong generalization of the findings. The researchers developed perception scales in consultation with the experts, one perception scale for students and another for teachers. The scales were developed on the basis of the five point attitude scale of Likert. The content validity ratio of the perception scale was found 0.99 , which was calculated by taking and merging the views of five experts in the field of education. The split-half reliability of the perception scale for teachers was .91 whereas the test reliability for the perception scale for students was .88 .

The perception scale for collection of data from students and teachers consisted of various components coming under the areas of CBCS like - the objectives of CBCS and their achievement, the problems faced by the teachers and students due to the CBCS at undergraduate level, perception in relation to the methodologies adopted by teachers under CBCS, perception in relation to the evaluation system and the perception of students in relation to the conduct of credit system and curriculum (Aitheli \& Kumar, 2016; Bhat, 2017; Chahal \& Manan, 2017; Dehuri, 2015; Ghose \& Sarkar, 2017; Kapur, 2017; Kotch, 2017; Singh, 2017; Tazien, 2017).

\subsection{Statistical Technique}

The researchers used " $\mathrm{t}$ " test to compare the mean scores of the teacher in relation to their stream, and students in relation to sex, stream, and type of college towards the implementation of Choice Based Credit System at the undergraduate level. 


\section{Analysis and Interpretation}

\subsection{Analysis of Data on the View of Teachers}

Table 1: Analyzing means scores of Arts and Science teachers towards the CBCS.

\begin{tabular}{|l|l|l|l|l|l|}
\hline $\begin{array}{l}\text { Teachers } \\
(\text { Stream) }\end{array}$ & N & Mean & SD & $\begin{array}{l}\text { 't' } \\
\text { value }\end{array}$ & Table value \\
\hline Arts & 20 & 97.7 & 6.29 & \multirow{2}{*}{.70} & 2.02 (at 0.05 level) \\
\cline { 1 - 1 } Science & 20 & 99.15 & 6.75 & & 2.71 (at 0.01 level) \\
\hline
\end{tabular}

\section{Mean Scores}

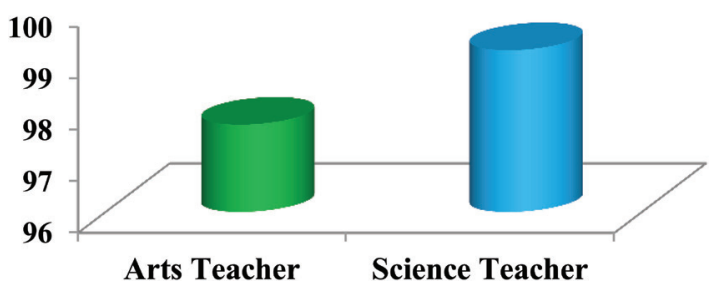

Figure 1: Mean scores of Arts and Science Teachers.

The analysis of Table- 1 indicates that the calculated score is smaller as compared to the existing table score at 0.01 and 0.05 level of significance in $38 \mathrm{df}$, hence there no statistical difference was found in between the perceptions of teachers towards the implementation of CBCS at the undergraduate level. It reflected that both the teachers of Arts and Science stream perceived the CBCS in the same direction. Although the Figure-1 reflects some difference between the mean score of Arts teacher (97.7) and Science teacher (99.15) was found, significantly there was no difference in between their perceptions towards the implementation of CBCS.

Table 2: Comparison of the mean scores of Science and Commerce teachers towards the CBCS.

\begin{tabular}{|c|c|c|c|c|c|}
\hline Teachers (Stream) & $\mathbf{N}$ & Mean & SD & 't' value & Table Value \\
\hline Science & 20 & 99.15 & 6.75 & \multirow{2}{*}{.75} & 2.02 (at 0.05 level) \\
\hline Commerce & 20 & 97.8 & 4.37 & & 2.71 (at 0.01 level) \\
\hline
\end{tabular}

\section{Mean Scores}

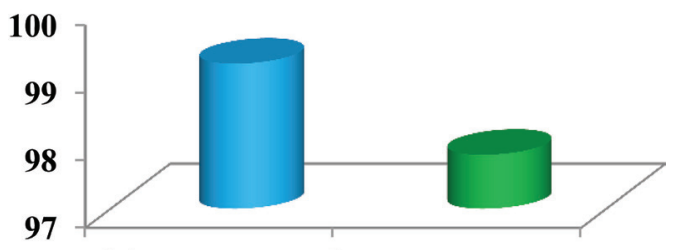

Science TeacherCommerce Teacher

Figure 2: Mean scores of Science and Commerce Teachers.
The analysis of Table- 2 reveals that the calculated ' $t$ ' score is lower than the table scores at the two levels, which revealed that the mean scores did not differ significantly in regards to the perceptions of science and Commerce teachers, they both perceived the implementation of CBCS at the same direction. Although the Figure-2 indicates a slight mean difference between the teachers from Science (99.15) and Commerce (97.8) stream, still when we say from statistical significance point of view there was no such difference.

Table 3: Examining mean scores of Arts and Commerce teachers towards the CBCS.

\begin{tabular}{|l|l|l|l|l|l|}
\hline $\begin{array}{l}\text { Teachers } \\
\text { (Stream) }\end{array}$ & N & Mean & S D & $\begin{array}{l}\text { 't' } \\
\text { value }\end{array}$ & Table value \\
\cline { 1 - 2 } Arts & 20 & 97.7 & 6.29 & \multirow{2}{*}{0.06} & 2.02 (at 0.05 level) \\
\cline { 1 - 1 } \cline { 6 - 7 } Commerce & 20 & 97.8 & 4.37 & & 2.71 (at 0.01 level) \\
\hline
\end{tabular}

\section{Mean Scores}

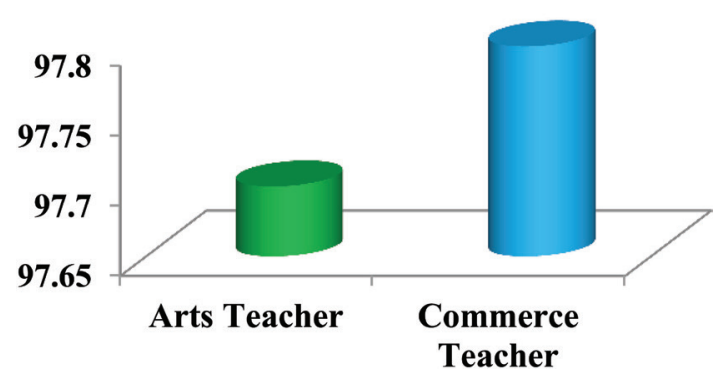

Figure 3: Mean scores of Arts and Commerce teachers.

The above Table-3 depicts information about the significance of the difference in between the perception of Arts and Commerce teachers, which reveals that the table score is greater than the calculated value, hence there exists no significant difference, both stream teachers perceived in same way towards CBCS. Although a slight difference was found in the mean of Arts teachers (97.7) and Commerce teachers (97.8), in relation to the statistical significance there is no any difference in their perceptions towards the implementation of CBCS.

\subsection{Analysis of data on the view of students}

Table-4: Judging mean scores of Male and Female students towards the CBCS.

\begin{tabular}{|l|l|l|l|c|l|}
\hline Students (Sex) & $\mathbf{N}$ & Mean & SD & 't' Value & Table value \\
\hline Male & 60 & 102.87 & 5.51 & & $\begin{array}{l}1.98(\text { at } 0.05 \\
\text { level) }\end{array}$ \\
${$\cline { 1 - 4 }$} }$ & 60 & 103.2 & 4.85 & .35 & $\begin{array}{l}\text { 2.62(at } 0.01 \\
\text { level) }\end{array}$ \\
\hline
\end{tabular}




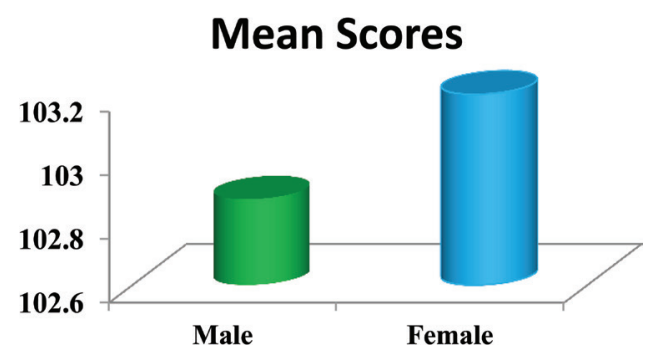

Figure 4: Male and Female students' mean scores.

The Table-4 represents information about the variations in between the perceptions of males and female towards the CBCS, which reveals that the obtained ' $\mathrm{t}$ ' score is not greater than the existing table scores at both levels, hence it was found that there was no such difference in their perceptions regarding the CBCS. Although the Figure- 4 represents a little bit mean the difference between the two, but in relation to statistical significance their perception is the same, no such difference was noticed.

Table 5: Comparing mean scores of Arts and science stream students towards CBCS.

\begin{tabular}{|l|l|l|l|l|l|}
\hline $\begin{array}{l}\text { Students } \\
\text { (Stream) }\end{array}$ & N & Mean & SD & $\begin{array}{l}\text { 't' } \\
\text { value }\end{array}$ & Table value \\
\hline Arts & 40 & 105.05 & 4.64 & \multirow{2}{*}{2.61} & 1.99 (at 0.05 level) \\
\hline Science & 40 & 102.05 & 5.62 & 2.64 (at 0.01 level) \\
\hline
\end{tabular}

The Table-5 reveals the perception of Arts and Science stream students towards the CBCS, it depicts that the obtained statistical score was higher than the table value at 0.05 level, so it can be said that the Arts and Science students perceive the CBCS differently and there exists significant difference in between their perceptions regarding $\mathrm{CBCS}$, however, the result was not found to be significant at 0.01 level. The Figure- 5 also represents that there exists mean the difference in between the perception of Arts and Science teachers, where the mean scores of Arts students are higher as compared to the science students.

\section{Mean Scores}

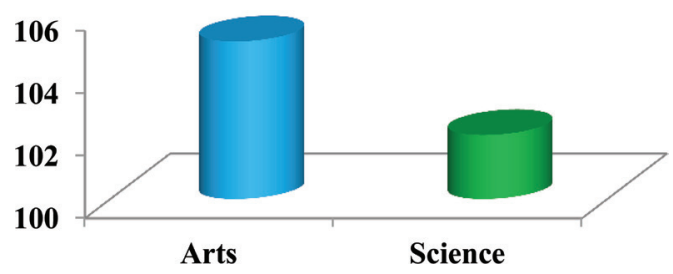

Figure 5: Mean scores of Arts and Science students.
Table 6: Analysis of mean scores of Science and Commerce stream student about CBCS.

\begin{tabular}{|l|l|l|l|l|l|}
\hline $\begin{array}{l}\text { Students } \\
\text { (Stream) }\end{array}$ & N & Mean & S D & 't' value & Table value \\
\hline Science & 40 & 102.05 & 5.62 & \multirow{3}{*}{3.58} & 1.99 (at 0.05 level) \\
\cline { 1 - 3 } Commerce & 40 & 107.1 & 7.01 & & $2.64($ at 0.01 level) \\
\hline
\end{tabular}

\section{Mean Scores}

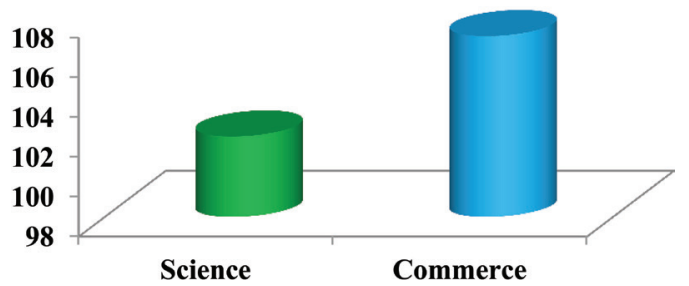

Figure 6: Mean scores of Science and Commerce students.

The Table- 6 depicts information about the significant difference in between the perceptions of students belonging from Science and Commerce stream towards the CBCS, which reveals that the table value is lower than the calculated value at both the 0.05 and 0.01 levels, by $38 \mathrm{df}$. Hence it revealed that we rejected the null hypothesis and concluded significance of the difference in between their perceptions. The Figure- 6 reveals that the mean score of Commerce students (107.01) is greater than the mean score of science students (102.05), which also gives statistical significance, so it can be said that their perceptions towards the implementation of CBCS differ significantly at both levels of significance.

Table 7: Evaluating the mean scores of Arts and Commerce students towards the CBCS.

\begin{tabular}{|l|l|l|l|l|l|}
\hline $\begin{array}{l}\text { Students } \\
(\text { Stream) }\end{array}$ & N & Mean & S D & $\begin{array}{l}\text { 't' } \\
\text { value }\end{array}$ & Table value \\
\hline Arts & 40 & 105.05 & 4.64 & \multirow{2}{*}{1.21} & $1.99($ at 0.05 level $)$ \\
\cline { 1 - 3 } \cline { 6 - 6 } Commerce & 40 & 107.1 & 7.01 & & $2.64($ at 0.01 level $)$ \\
\hline
\end{tabular}

\section{Mean Scores}

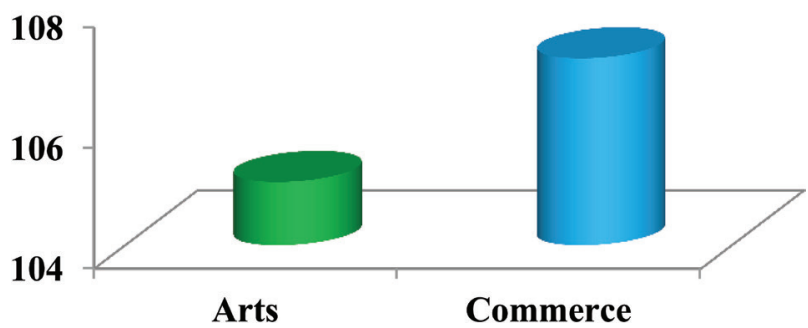

Figure 7: Mean scores of Arts and Commerce students. 
The Table-7 represents information about the statistical mean difference between the perceptions of Arts and Commerce learners about CBCS, which reveals that the obtained ' $\mathrm{t}$ ' value was found to be smaller than the table values at both the 0.05 and 0.01 levels, so we accepted the null hypothesis which revealed no statistical significant difference in between their perceptions about the CBCS. Although the Figure-7 depicts information that the slight difference between the mean of Arts students (105.05) and mean of Commerce students (107.1), statistically there exists no such difference in their perceptions regarding the implementation of CBCS at HEIs.

Table-8: Comparison of the mean scores of students of private and government colleges.

\begin{tabular}{|l|l|l|l|l|l|}
\hline $\begin{array}{l}\text { (Students) Type } \\
\text { of College }\end{array}$ & $\mathbf{N}$ & Mean & S D & $\begin{array}{l}\text { 't' } \\
\text { value }\end{array}$ & Table value \\
\hline Private & 30 & 102.56 & 4.47 & \multirow{2}{*}{2.04} & 2.00 (at 0.05 level) \\
\hline Government & 30 & 100.33 & 4.02 & & 2.66 (at 0.01 level) \\
\hline
\end{tabular}

\section{Mean Values}

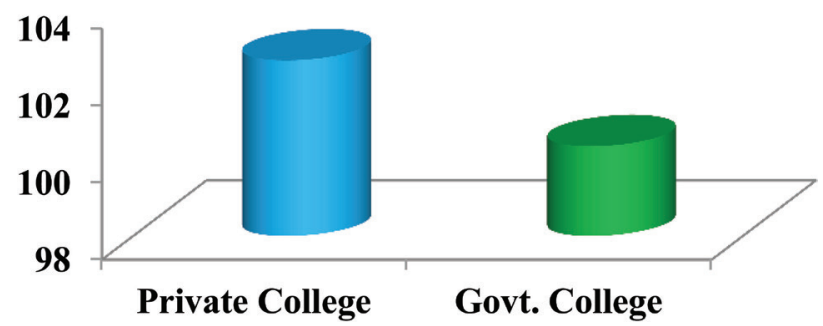

Figure 8: Mean values of Private and Govt. college students.

The above Table- 8 represents information about the significant difference in between the perception of students belonging from private and government colleges, which reveals that the obtained ' $\mathrm{t}$ ' value was showed to be greater as compared to 0.05 level, so here the null hypothesis was statistically rejected which concluded that there was significance of difference in their perceptions, but on the other hand at 0.01 level, the null hypothesis was accepted as the $t$ value was found to be less than the table value. Although the Figure- 8 depicts information about the mean scores of private college students (102.56) and government college students (100.33), statistically such difference is found in their perceptions in one hand, and in other, no such difference is found.
Table 9: Mean difference between the students of Government and government aided colleges.

\begin{tabular}{|c|c|c|c|c|c|}
\hline $\begin{array}{l}\text { (Students) Type of } \\
\text { College }\end{array}$ & $\mathbf{N}$ & Mean & $S$ D & $\begin{array}{l}\text { 't' } \\
\text { value }\end{array}$ & Table value \\
\hline Government & 30 & 100.33 & 4.02 & \multirow[b]{2}{*}{4.29} & 1.99 (at 0.05 level) \\
\hline Government Aided & 60 & 104.71 & 5.67 & & 2.63 (at 0.01 level) \\
\hline
\end{tabular}

\section{Mean Scores}

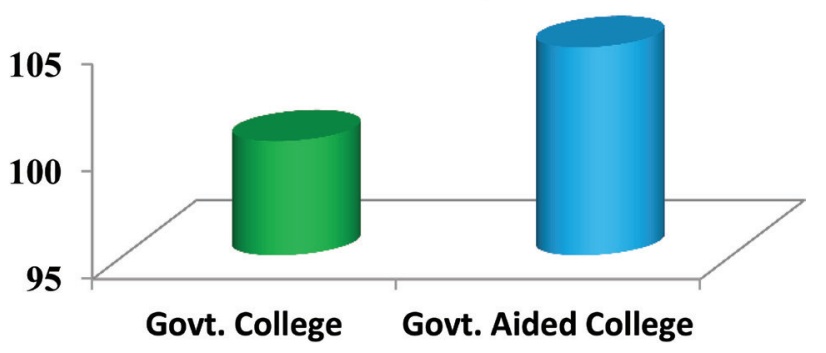

Figure 9: Mean scores of Govt. and Govt. Aided College Students.

The above Table- 9 depicts information about the mean difference in between the perceptions of govt. college student and govt.-aided college student, which revealed that the table value is lower as compared to the calculated ' $\mathrm{t}$ ' value at both the 0.05 and 0.01 levels, hence the $\mathrm{H}_{0}$ was rejected which revealed the variations in between their perceptions in the form of mean regarding the CBCS. In this regards the Figure-9 depicts that the mean score of government college students (100.33) and government aided college students (104.71) are different and statistically also significant in both the levels of significance, hence their perceptions differ significantly.

Table 10: Significant difference between the two mean scores of students from private and government aided colleges.

\begin{tabular}{|l|l|l|l|l|l|}
\hline $\begin{array}{l}\text { (Students) Type } \\
\text { of College }\end{array}$ & N & Mean & S D & 't' value & Table value \\
\hline Private & 30 & 102.56 & 4.47 & \multirow{2}{*}{1.97} & 1.99 (at 0.05 level) \\
\cline { 1 - 3 } Govt.-Aided & 60 & 104.71 & 5.67 & & 2.63at 0.01 level) \\
\hline
\end{tabular}

The above Table-10 represents information about the difference between the means of private college student and government aided college student towards the implementation of CBCS, which showed that the obtained ' $\mathrm{t}$ ' value was lower as compared to the table values at both the levels, so statistically the $\mathrm{H}_{0}$ was approved, which stated no mean difference in their perceptions regarding the CBCS. Although the above Figure-J reveals a slight mean difference of private 
college students (102.56) and govt. aided college students (104.71), but statistically they both didn't differ significantly.

\section{Mean Scores}

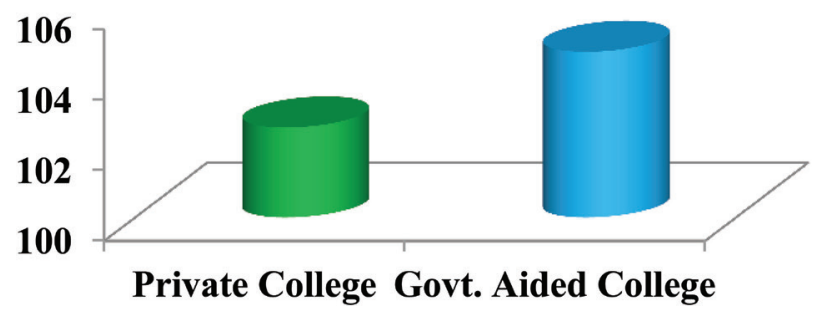

Figure 10: Mean scores of Private and Govt. Aided college students.

\section{Results and Discussion}

- The analysis and interpretation of the data revealed that there were no statistical mean variations between the perception of Arts and Science teachers towards the implementation of CBCS at the undergraduate level.

- It was also found that the perceptions of Science and Commerce teachers did not differ significantly in relation to the CBCS.

- Arts and Commerce teachers did not differ significantly in their perception towards the implementation of CBCS at the undergraduate level.

- The perceptions boys and girls students were not different from each other towards the implementation of CBCS.

- A significant difference was found in the perception students belonging from Arts and Science stream towards the CBCS at the undergraduate level, their perceptions were somehow varied with reference to the implementation of CBCS.

- The Science and Commerce stream students perceived differently in regards the implementation of CBCS.

- No, any kind of statistical difference was found in between the perception of Arts and Commerce students towards the implementation of CBCS.

- The perceptions regarding CBCS were different in case of government and private college students, as their means differed from one another.

- The govt. and govt.-aided college students perceived in a different way towards the implementation of CBCS.

- The perception of private and government aided college students' varied from each others towards the implementation of CBCS.

The study revealed mean difference in the perception of Arts and Science students. This finding was matched with the findings of Bhat (2017) and Deuri (2015), where as Bhat (2017) concluded that the attitude of science students were higher as compared to Arts students at the undergraduate level in government degree colleges of Anantanag Kashmir. Deuri (2015) studied at Gauhati University and the result revealed that there was difference in the attitude of Science and Arts students, where the mean scores of Science students were found higher. The science stream learners also differed significantly from the Commerce students in their perception towards the implementation of CBCS at the undergraduate level. But Arts and Commerce students did not differ significantly in their perception of CBCS. The present study also expressed that there was no such difference in the perceptions of male and females towards CBCS. This finding opposed to the findings of Deuri (2015) who found that the boys are having the highest level of an attitude than the girls in Gauhati University. It was analyzed from the study that the the perceptions of teachers in relation to streams (Arts, Science, and Commerce) didn't differ significantly towards CBCS. Like that, Kotch (2017) also found similarities in the attitude of male and female, urban and rural, more experienced and less experienced teachers of degree colleges towards CBCS in Hamirpur district of Himachal Pradesh.

\section{Suggestions for Further Studies}

- One comparative study can be undertaken to compare the perception of teachers and students of undergraduate or postgraduate level towards the CBCS.

- A survey research can be undertaken to study the status of CBCS by expanding the scope and delimitations of the study.

- This type of work can be undertaken in other parts of the country, as the CBCS is centrally implemented.

- An experimental study can be undertaken to examine the impact of CBCS on academic achievement, quality of education, etc.

- The perception and attitude of all the stakeholders can be taken into account and a survey may be undertaken.

- A qualitative study or mixed study may be undertaken to examine the CBCS pattern as a whole.

\section{Conclusion}

The tertiary level of education i.e. higher education in any country is the backbone for bringing about all-round 
development where its role cannot be underestimated. The adoption of the Choice Based Credit System (CBCS) at the higher level is a milestone in bringing a major reform in curriculum and examination system as a whole, particularly in India. This is really better than the traditional system of education and mark based evaluation as perceived by the students and teachers of HEIs. The effective implementation of CBCS will bring a drastic change in the overall structure of higher education and will produce more active, productive, skillful, knowledge and highly employable students. In order to make it successful in all contexts, there is a need of more research-based innovations and systematic planning towards its better implementation, which is possible only because of the integrations of the stakeholders of HIEs. However, after analyzing the perception of both teachers and students of undergraduate level, finally it can be concluded that the samples of Bargarh district, Odisha perceived the implementation of CBCS positively, as no such statistical differences were found and the statements of the scale were positive. Still, in some cases, the perception of the students of differed, so in that regard awareness level of the students can be developed thoroughly.

\section{Acknowledgement}

For the present research work we are very much thankful to the Gangadhar Meher University, Sambalpur, Odisha for providing such an opportunity to undertake the research. We are also very much thankful to the principals of degree colleges of Bargarh district for providing necessary data for research purposes, without which it would never been successful.

\section{Funding Details}

We have not received any financial grant from any person or agency in completing this research work. This work is the result of our self-funding.

\section{Disclosure Statement}

No potential conflict is reported.

\section{References}

Aithali, P. S. \& Kumar, P. M. S. (2016). Analysis of choice based credit system in higher education. International Journal of Engineering Research and Modern education (IJERME), 1(1), 278-284.

Behera, S., Meher, V. \& Baral, M. (2018). Perception of teachers and students towards the implementation of semester system of examination at undergraduate level. Edited by S. Rout, Examination reforms for quality higher education in India: Opportunity and challenges (pp. 246-252), New Delhi: New Delhi Publishers. Retrieved from: https://www.researchgate. net/publication/333021239

Bhat, S. M. (2017). Attitude towards choice based credit system of graduate level students in higher education: A study on government Degree College for women Anantanag Kashmir. International Refereed \& Blind Peer-Reviewed Research Journal, 6(3), 47-51.

Biswas, S. (2018). Choice based credit system -An analytical study. International Journal of Research and Analytical Study, 5(3), 1362-1368.

Chahal, D. \& Manan, M. M. (2017). Attitude towards choice based credit system of postgraduate level students in higher education: A study on the central university of Haryana. Sambad: e-Journal, 6(2), 163-193.

Deuri, C. (2015). Attitude towards choice based credit system of the postgraduate level students in higher education: A study on Gauhati University. International Journal of Interdisciplinary Research in Science Society and Culture, 1(2), 115-122.

Ghose, R. \& Sarkar, B. (2017). Choice based credit system (CBCS)-A new reform in education. EPRA International Journal of Research and Development (IJRD), 2(7), 85-89.

Hasan, M. \& Parvez, M. (2015). Choice based credit system In India: Pros and Cons. Journal of Education and Practice, 6(25), 30-33.

Kapur, S. (2017). Choice based credit system and higher education in India. Jamia Journal of Education, 3(2), 100-110.

Kaur, A., \& Sharma, M. (2016). Academic curriculum reform of Indian higher education: Choice based credit system. International Journal of Advanced Research in Education \& Technology, 3(1), 78-80.

Kelkar, A. S. \& Ravishankar, L. (2014). Choice-based credit system: boon or bane? Current science, 107(8), 12-30.

Kotch, S. K. (2017). Choice based credit system (CBCS): Attitude of college teachers, Pedagogy of Learning, 3(1), 27-35. 
Mishra, S. P. (2017). Introduction to choice based credit system: A new paradigm shift in higher education, Scholarly Research Journal for Humanity Science \& English Language, 4(21), 4869-4877.

Naidu, B. V. R., \& Sreedevi, O. V. A. M. (2016). The choicebased credit system in India: A critical evaluation. International Journal of Academic Research, 3(2), 77-84.

Shivasakthy, M., Sethuraman, K. R. \& Adkoli, B. V. (2016). Acceptability and feasibility of the choice based credit system in BDS Syllabus. International Journal for Innovation Education and Research, 4(7), 73-80.
Singh, M. (2017). Perception of Student Teachers towards CBCS for Quality Sustain, International Journal of Research in all Subjects in Multi-languages, 5(11), 60-62.

Sumitha, P. V., Krishnamurthy, M. G. \& Winfred, B.R. (2016). An Empirical Study to measure the perception of management students towards choice based credit system: A Case Study. IOSR Journal of Business and Management (ISOR-JBM), 55-65.

Tazien, W. (2017). The choice-based credit system in India: A critical review of related literature. The Scholar, 1(4), $7-21$.

\section{峝 CHITKARA}

\section{Issues and Ideas in Education}

Chitkara University, Saraswati Kendra, SCO 160-161, Sector 9-C, Chandigarh, 160009, India

\section{Volume 7, Issue 1}

March 2019

ISSN 2320-7655

Copyright: [C 2019 Venkateswar Meher et al.] This is an Open Access article published in Issues and Ideas in Education (Issues Ideas Educ.) by Chitkara University Publications. It is published with a Creative Commons Attribution- CC-BY 4.0 International License. This license permits unrestricted use, distribution, and reproduction in any medium, provided the original author and source are credited. 